\title{
Public Relations Professionals' \\ Communication Strategies in \\ Responding to the COVID-19 \\ Pandemic Based on Gender
}

Nobertus Ribut Santoso, Emanuela Agra Sarika Kurnia

Dewi, Heidy Arviani, and Zainal Abidin Achmad

\begin{abstract}
Many studies have examined crisis management in various business sectors. However, COVID-19 has presented unique and interesting challenges. Using an online survey $(n=224$ participants $)$ and indepth interviews, profiling public relations professionals' communication strategies in responding to the COVID-19 pandemic based on gender was investigated. The findings reveal that male and female public relations practitioners have specific understandings of the COVID-19 pandemic, ways in facing the crisis, and differing public relations activities during the pandemic. They regard this pandemic as a challenge to be adoptive, innovative, and creative, enhance technology competencies, and build relationships with publics by providing up to date information. Female public relations practitioners use social media more than males and give more attention to communication programs dealing with customers, while male counterparts focus on capturing the market by strengthening the organization's image and reputation through publicity in conventional media.
\end{abstract}

Keywords: gender, public relations professionals, crisis communication, communication strategies, COVID-19 pandemic 


\section{Plaridel Open Access Policy Statement}

As a service to authors, contributors, and the community, Plaridel: A Philippine Journal of Communication, Media, and Society provides open access to all its content. To ensure that all articles are accessible to readers and researchers, these are available for viewing and download (except Early View) from the Plaridel journal website, provided that the journal is properly cited as the original source and that the downloaded content is not modified or used for commercial purposes. Plaridel, published by the University of the Philippines College of Mass Communication is licensed under Creative Commons Attribution-NonCommercial-NoDerivatives 4.0 International License (https://creativecommons.org/ licenses/by-nc-nd/4.0/legalcode).

\section{How to cite this article in APA}

Santoso, N.R., Dewi, E.A.S.K., Arviani, H., Achmad, Z.A. (2021). Public relations professionals' communication strategies in responding the covid-19 pandemic based on sexes. Plaridel, 18(1), 295-315. https://doi.org/10.52518/2021.18.1-08saderac 


\section{Introduction}

The COVID-19 pandemic has disturbed on an unprecedented level all structures of life (Mahar, 2020). This virus has destroyed global economies, causing inflation and unemployment in the millions. This situation reached crisis proportions since most organizations were glossy unprepared (Hudecheck et al., 2020). Revenues significantly dropped in a matter of weeks. Reactive actions were taken by many organizations to prevent further losses, such as implementing a work-from-home system, protecting supply chains, reducing the number of employees, cutting budgets, and asking the government for help (Wade \& Bjerkan, 2020).

In Indonesia, for example, the International Labour Organization (ILO) SCORE Indonesia reported that among 571 companies that they surveyed in April 2020, two out of three companies were temporarily or permanently closed. One fourth of them lost more than a half of their revenue. To keep surviving, they negotiated with banks, suppliers, and employees. ILOSCORE Indonesia also found that sixty-three percent of the surveyed companies minimized the number of employees while others indicated that they would follow this policy. In responding the needs of the customers, one out of five companies uniquely differentiated their products while one third of them shifted their business activities online (ILO-SCORE Indonesia, 2020).

The global crisis brought about by the COVID-19 pandemic challenged business organizations to quickly adopt to the situation through crisis communication. Crisis communication is the collection, processing, and dissemination of information to protect the image and reputation of an organization (Campbell \& Craig, 2005). Proper crisis management will give organizations opportunities for security and development. If an organization fails to handle the crisis, it will lose the trust of stakeholders (Coombs, 2007).

Meanwhile, employees on all levels are being asked to adjust to this situation since the pandemic changes the way professional and social interaction among employees and with public. In response to this crisis, public relations professionals should ensure principles of good communication to understand key stakeholders, maintain relationships with them (Wu et al., 2020), and reduce uncertainties (Olsson, 2014). Different communication tactics are also required to effectively establish crisis management in response to this global pandemic by providing a clear guidance. Public relations professionals should provide a clear, optimistic vision and a realistic plan, take decisive action, facilitate open, honest, and frequent communication (Wu et al., 2020), and provide relevant communication (Marra, 1998). 
In facing the crisis, the organization should put public relations practitioners in the crisis management team (Coombs, 2007) since they are expected to be able to develop communication plans that take into account both opportunities and threats (Marra, 1998). Coombs (2010) argued that a crisis is characteristically a threat that can destroy the reputation of an organization. However, how the crisis is managed determines if the outcomes are threats or opportunities. Therefore, public relations professionals play an essential role in this pandemic, since they function as communication managers helping the organization to find the best solution to survive in this hard time and to maintain relationship with all publics.

In responding to the crisis, public relations professionals should have crisis communication strategies emphasizing the future and how things will be better for the organization and its stakeholders. These strategies should also include reputation repair (Campbell \& Craig, 2005). Public relations professionals should help management develop messages before sending them to various publics by using all channels (Coombs, 2007). Due to the crisis, social media has become a vital tool to disseminate information to the stakeholders, helping organizations connect and engage with them to maintain trust during this difficult time (Olsson, 2014).

The COVID-19 pandemic challenges public relations practitioners to develop communication plans since communication strategies that were previously planned became frozen. The role of public relations practitioners in tackling this pandemic situation is crucial since they are communication specialists that craft messages (Fall, 2004) by using various platforms, methods, and channels. As excellent communicators, they should understand the targeted audiences' knowledge, beliefs, attitudes, and concerns (Flynn, 2014). Moreover, communication strategies that have been designed should help public relations practitioners gather and release information as quickly as possible (Marra, 1998).

Public relations strategies in this pandemic should be sensitive to the situation faced by society. Public relations should keep telling the stories of the organization by considering their relevance to the situation. Public relations should also be helpful and fast in responding to the pandemic. In this situation, publics will evaluate which brands or organizations are reacting and taking care of the publics (Marx, 2020).

In facing the crisis, male and female public relations practitioners have different responses. This can be attributed to each organization having a different nature of business with different objectives that effect different communication strategies (Campbell \& Craig, 2005, p. 26). However, there is still a lack of current studies to differentiate the ways that male and female practitioners handle the crisis. Roxana Manolescu's (2016) study focusing 
on media coverage of the organization due to a crisis reveals that female practitioners get more positive coverage than male practitioners. This difference arises due to a gender field (Daymon \& Demetrious, 2010) where people conclude that the public relations profession has feminine values such as honesty, justice, and sensitivity (Andsager \& Hust, 2005). Research on profiling public relations professionals' communication strategies in responding to the COVID-19 pandemic based on gender has not yet been undertaken. The present research contributes to knowledge in crisis management in the COVID-19 pandemic particularly from the perspective of gendered public relations.

\section{Methods}

This study employed mixed methods incorporating elements of both quantitative and qualitative approaches in order to provide a more complete understanding of an interesting phenomenon (Creswell, 2014). Qualitative data deeply supported the quantitative data.

First, an online survey was conducted from April 29 to May 22, 2020. Given the pandemic, the survey's online nature made it easy to administer and be accessed with any device by participants from Indonesia. The survey was closed after getting responses from 224 participating public relations practitioners, including 96 males and 128 females. They were from 29 different organizations or business sectors and had working experiences as public relations practitioners for less than 3 years $(38.82 \%)$, for 4-7 years (27.23\%), for $8-11$ years (19.64\%), and for $12-15$ years $(11,16 \%)$. The fewest participants had working experiences for more than 15 years.

Virtual snowball sampling was employed in this study since it was hard to reach the participants in this pandemic of COVID-19 (Baltar \& Brunet, 2012). This study used social media, such as Facebook, Instagram, WhatApps, and LinkedIn, to facilitate the online survey distribution. We also asked the participants to share the online survey to their friends also working as public relations practitioners.

The instrument was composed of partially open-ended questions consisting of three main questions based on the two main concepts including a concept of crisis and ways in dealing with the crisis and a brief demographic part. The average time to complete the survey was approximately 13 minutes. Each participant could choose several answer options according to the circumstances they dealt with. The first question asked the participants to identify their perspective towards the crisis consisting of 12 possible answers. The second question asked the participants' ways of facing the crisis consisting of 8 possible answers. The 
last question asked the participants to identify public relations activities during the COVID-19 pandemic consisting of 13 possible answers.

After conducting the online survey, six informants were purposively chosen to be personally interviewed to get in-depth data to increase an understanding of the underlying phenomenon regarding their responses. They were asked about their views of the COVID-19 pandemic and their programs in dealing with it. The main questions were followed up with in-depth questions to encourage informants to narrate and describe their experiences in dealing with the pandemic. An equal number of males and females, three of each, was considered to elicit as much diversity in the data that would contribute to the body knowledge on gender and public relations. The six respondents represented six business sectors that dominated the survey, namely education, hotel, hospital, government, agency, and media. All of them were public relations professionals handling the communication crisis caused by the COVID-19 pandemic. In selecting the six informants, one individual from each dominant business sector was randomly asked to volunteer as a respondent, while following the three male-three female requirement. They were chatted through the WhatsApp number that they provided in the online survey. Those who volunteered to be informants were interviewed via WhatsApp call.

Table 1. Informants' Profile

\begin{tabular}{|c|c|c|}
\hline Informants & Gender & Business Sectors \\
\hline Informant 1 & Male & Hospital \\
\hline Informant 2 & Male & Education \\
\hline Informant 3 & Female & Hotel \\
\hline Informant 4 & Female & Media \\
\hline Informant 5 & Male & Government \\
\hline Informant 6 & Female & Agency \\
\hline
\end{tabular}

Responses to the survey were tabulated and reported in the form of percentages. Meanwhile, the responses to the interviews were transcribed and then categorized based on the online survey questions and answer options. The interview data supported the tabulated data in percentage form. Moreover, reflexivity was used to acknowledge the researchers' bias and position. 


\section{Result}

\section{Public Relations' Understandings of the COVID-19 Pandemic}

Most public relations practitioners face a crisis at one time or another. Therefore, acknowledging their perception of crisis becomes essential before understanding how they handle it.

Table 2. Public Relations' Understanding of the COVID-19 Pandemic

\begin{tabular}{|c|c|c|c|c|}
\hline \multirow{2}{*}{$\begin{array}{l}\text { PR's Understanding of the } \\
\text { COVID-19 Pandemic }\end{array}$} & \multicolumn{2}{|c|}{ Males $(\mathrm{N}=96)$} & \multicolumn{2}{|c|}{ Female $(\mathrm{N}=128)$} \\
\hline & Frequency & Percentage & Frequency & Percentage \\
\hline Making the job harder & 17 & 17.7 & 14 & 11 \\
\hline Inhibiting the development & 11 & 11.5 & 16 & 12.5 \\
\hline Bothering programs planned & 32 & 33.3 & 38 & 30 \\
\hline $\begin{array}{l}\text { Encouraging to develop its } \\
\text { creativity }\end{array}$ & 71 & 74 & 94 & 73.4 \\
\hline Opportunities to develop & 29 & 30.2 & 35 & 27.3 \\
\hline Challenging to innovate & 68 & 70.8 & 81 & 63.3 \\
\hline $\begin{array}{l}\text { Opportunities to re-plan } \\
\text { communication strategies }\end{array}$ & 70 & 73 & 96 & 75 \\
\hline Challenging to quickly adapt & 75 & 78.1 & 99 & 77.3 \\
\hline $\begin{array}{l}\text { Challenging to understand } \\
\text { customers' needs }\end{array}$ & 48 & 50 & 72 & 56.3 \\
\hline Challenging to keep public trust & 61 & 63.5 & 90 & 70.3 \\
\hline Threatening image & 10 & 10.4 & 10 & 7.8 \\
\hline $\begin{array}{l}\text { Threatening organizational life } \\
\text { cycle }\end{array}$ & 22 & 23 & 20 & 15.6 \\
\hline
\end{tabular}

Table 2 presents in twelve categories the male and female public relations practitioners' perception of the COVID-19 pandemic. The majority of both male and female public relations practitioners positively acknowledged the COVID-19 pandemic as a challenge to quickly adopt (male $=78.1 \%$, female $=77.3 \%$ ), an opportunity to re-plan communication strategies (male $=73 \%$, female $=75 \%$ ), an encouragement to develop creativity (male $=74 \%$, female $=73.4 \%)$, a challenge to innovate (male $=70.8 \%$, female $=63.3 \%$ ), and a challenge to keep the public trust (male $=63.5 \%$, female $=70.3 \%$ ). On the other hand, only few public relations practitioners acknowledged the pandemic as threatening image (male $=10.4 \%$, female $=7.8 \%$ ), making jobs harder $($ male $=17.7 \%$, female $=11 \%)$, inhibiting development $($ male $=$ $11.5 \%$, female $=12.5 \%$ ), and threatening organizational life cycles (male $=$ $23 \%$, female $=15.6 \%$ ).

The interviews with six public relations practitioners revealed that organizations followed government's official protocols to deal with the 
COVID-19, which aimed to protect the public since safety became a priority. "In my place, the adaptation is based on the instructions or commands from the government. We try to adopt government's instructions towards health protocols. It is the first step to protect faculty members and students," said male informant 2. Informant 4, a female, shared, "By following the health protocols, in our live program, we usually invite speakers in our news studio. Because of the Covid-19, what we can do is broadcasting via Zoom.”

To survive in this disruption, organizations came up with strategic policies and adaptive programs, and also sped up its products' innovation with the aim to sustain growth. Digital innovation became the best solution to save businesses since technology is already central to our lives. "We develop telemedicine service for publics," said male informant 1 .

In this crisis, the pre-planned direct programs of public relations practitioners have shifted to digital activities. By using the powerful digital platform that is social media, they can connect and maintain communication with their publics. Social media also help organizations combat the COVID-19 pandemic by creatively creating contents to engage its publics. The use of these platforms can also improve and boost brand awareness for the organization. As indicated by informant 1, "Managing social media is to develop brand awareness of our hospital."

The uncertainty, fear, and confusion brought about by the COVID-19 pandemic compelled organizations to re-evaluate their communication strategies to mitigate losses and gain, maintain, and reinforce public trust by being open and honest. Informant 4 said, "For our television, hmm, whatever we do, we have to produce news that is actual, accurate, and credible." Thus, organizations shifted from direct communication programs to digital. This change is based on the change of public behavior in consuming media due to the pandemic. "By using visual video, we want to communicate to publics that we are still here, and we also communicate about tourism in Yogyakarta, communicate our new packets, and we are also active in social media," said female informant 3. Through digital channels, organizations can provide the public with information that is clear, complete, and accurate. Such strategies can prevent further problems.

Strategies in this crisis consider how to engage with the public by building a brand image and developing brand awareness through online platforms, and communicating the organizations and their values. Twoway communication between organizations and their publics is critical to ensure that the latter are heard. "We do two-way communication intensively to all patients in our hospital, both inpatient and outpatient cares. This is done to monitor and evaluate our services in order to get feedbacks," said informant 1. Moreover, the COVID-19 pandemic provides opportunities 
to strengthen public trust as long as the organizations can develop services and optimize the use of digital media to communicate what their activities, particularly their improvement and achievements.

\section{Ways of Public Relations in Facing the COVID-19 Pandemic}

Table 3 shows public relations practitioners' ways to face the COVID-19 crisis. In general, both male and female respondents tended to develop technology competencies and skills such as optimizing the use of digital/ online media ( male $=92.7 \%$, female $=93.8 \%$ ), improving the ability to master information technology (male $=75 \%$, female $=73.4 \%$ ), exploring new platforms (male $=72.9 \%$, female $=65.6$ ), and sharpening creativity to create contents (male $=66.7 \%$, female $=68.8 \%$ ). On the other hand, male public relations practitioners tended to enlarge more communication with external publics (59.4\%) while their female counterparts tended to enlarge communication with internal publics (43.8\%).

Table 3. Ways of PR in Facing the COVID-19 Pandemic

\begin{tabular}{|c|c|c|c|c|}
\hline \multirow{2}{*}{$\begin{array}{l}\text { Ways of PR in Facing the } \\
\text { COVID-19 Pandemic }\end{array}$} & \multicolumn{2}{|c|}{ Males $(\mathrm{N}=96)$} & \multicolumn{2}{|c|}{ Female ( $\mathrm{N}=128)$} \\
\hline & Frequency & Percentage & Frequency & Percentage \\
\hline $\begin{array}{l}\text { Sharpening creativity to create } \\
\text { contents }\end{array}$ & 64 & 66.7 & 88 & 68.8 \\
\hline $\begin{array}{l}\text { Enlarging communication with } \\
\text { external public }\end{array}$ & 57 & 59.4 & 55 & 43 \\
\hline $\begin{array}{l}\text { Enlarging communication with } \\
\text { internal public }\end{array}$ & 36 & 37.5 & 56 & 43.8 \\
\hline $\begin{array}{l}\text { Increasing knowledge and skills } \\
\text { to understand current issues }\end{array}$ & 60 & 62.5 & 83 & 64.8 \\
\hline $\begin{array}{l}\text { Exploring new platforms to } \\
\text { communicate with public }\end{array}$ & 70 & 72.9 & 84 & 65.6 \\
\hline $\begin{array}{l}\text { Improving the ability to master } \\
\text { information technology }\end{array}$ & 72 & 75 & 94 & 73.4 \\
\hline $\begin{array}{l}\text { Optimizing the use of digital/ } \\
\text { online media to work }\end{array}$ & 89 & 92.7 & 120 & 93.8 \\
\hline $\begin{array}{l}\text { Limiting to directly meet the } \\
\text { public }\end{array}$ & 53 & 55.2 & 69 & 53.9 \\
\hline
\end{tabular}

During the COVID-19 crisis, most employees were forced to work from home to keep safe and cut the virus's spread. Therefore, mastering information technology became a challenge of remote working. Employees were encouraged to learn and adapt information technology to help them perform their duties. Public relations practitioners independently learned how to optimize the use of information technology since it helped them to 
disseminate information to both internal and external publics. To optimize the use of organization-level information technology, informant 1, informant 2 , and informant 3 said that they coordinated with their information technology department for support and with other public relations staff also in the process of mastering information technology. Meanwhile, those working in organizations that were already using digital media as core tools did not need to enhance their capability to use information technology since it has been part of their daily activities.

The importance of mastering information technology was spurred by the challenge for public relations practitioners to keep connecting and engaging with its publics. Creating creative content became the solution to address all publics since it could be quickly delivered and communicated through digital media. "We create contents about medical services during the pandemic and tips for staying healthy delivered lightly and easily understood by the publics," said informant 1 . Public relations practitioners related their content to the situation faced by the publics to show their organizations' sensitivity.

Although public relations practitioners are forced to enhance their creativity, the quality and standards of their content should follow the organization's guidelines. Moreover, before making new creative content, public relations practitioners monitor and explore social media trends in order to identify essential issues discussed by social media users. This ensures that the content will relate to what the publics talk about on social media, which is pivotal to public relations activities' success. "We create contents about medical services during the pandemic and tips for staying healthy delivered lightly and easily understood by the publics," said informant 1 . In the line with Informant 1, female informant 6 shared that "Our creativity in making contents should be related to pandemic and health protocols."

Enhancing knowledge and skills to understand current issues help public relations practitioners understand what the public needs. "Because, all this time, the information we have released to publics, as we think, is important. But, in fact, it is not like we think," said male informant 5. A popular activity available to practitioners aiming to update their understanding of current issues and develop their skills was webinars discussing social media management and communication strategies during and post COVID-19 pandemic. "There were many webinars I joined such as social media management due to the Covid-19 and tourism and communication strategies. These can help me to find out information and policies of the government towards tourism" (Informant 3, female). In keeping with informant 3, Informant 6 (female) shared "By joining webinar, I can update current condition and improve my public relations knowledge." 
Due to the COVID-19 pandemic, enlarging communication with internal and external publics is crucial since they influence and support the organizations' existence. Male public relations practitioners tended to expand communication with the external public. Informant 5 explained that "If we are more external, internal communication is more in the household department. If we communicate more to the external publics, then we will use online media more." Meanwhile, female public relations practitioners gave more attention to communicating with internal publics to strengthen and optimize the internal organization. "So, like it or not, internal communication must be strengthened. Employees should be given an understanding of why we are like this. So, this should always be communicated to employees so that they are also not discouraged, so that they can still work well. Come on, we can deal with this problem together," said informant 3 .

\section{Public Relations Activities during the Pandemic}

Table 4 presents what male and female public relations practitioners did during the COVID-19 pandemic to save their organizations. Implementing events involving public participation physically has the lowest percentage among the public relations activities. Some activities have similar percentage between males and females such as managing website as official information source $($ male $=72.9 \%$, female $76.6 \%)$ and internal media $($ male $=60.4 \%$, female 61.7\%), communicating and coordinating with government (male $=55.2 \%$, female $=55.5 \%$ ), and maintaining internal (male $=78.1 \%$, female $=82 \%$ ) and external (male $=80.2 \%$, female $=80.5 \%$ ) communication. On the other hand, although managing social media has a high percentage of males $(75 \%)$, female public relations practitioners have a higher percentage (85.2\%).

Some other public relations activities have significant differences between males and females. Male public relations practitioners tended to implement community relations programs $(49.9 \%)$, conduct media relations activities $(67.7 \%)$, and write press releases $(78.1 \%)$ more than their female counterparts. Meanwhile, female public relations practitioners tended to implement CSR programs (62.5\%), address and resolving customer complaints (62.5\%), and update organizational information to customers (71.1\%) more than their male counterparts. 
Table 4. PR Activities during the COVID-19 Pandemic

\begin{tabular}{|c|c|c|c|c|}
\hline \multirow{2}{*}{$\begin{array}{l}\text { PR Activities during the } \\
\text { COVID-19 Pandemic }\end{array}$} & \multicolumn{2}{|c|}{ Males $(\mathrm{N}=96)$} & \multicolumn{2}{|c|}{ Female $(\mathrm{N}=128)$} \\
\hline & Frequency & Percentage & Frequency & Percentage \\
\hline $\begin{array}{l}\text { Managing website as official } \\
\text { information source }\end{array}$ & 70 & 72.9 & 98 & 76.6 \\
\hline Managing social media & 72 & 75 & 109 & 85.2 \\
\hline Managing internal media & 58 & 60.4 & 79 & 61.7 \\
\hline $\begin{array}{l}\text { Events involving public } \\
\text { participation physically }\end{array}$ & 16 & 16.7 & 15 & 11.7 \\
\hline Implementing CRS programs & 53 & 52.2 & 80 & 62.5 \\
\hline $\begin{array}{l}\text { Implementing community } \\
\text { relations programs }\end{array}$ & 46 & 49.9 & 52 & 40.6 \\
\hline $\begin{array}{l}\text { Addressing and resolving } \\
\text { customer complaints }\end{array}$ & 48 & 50 & 71 & 55.5 \\
\hline $\begin{array}{l}\text { Communicating and coordinating } \\
\text { with government }\end{array}$ & 53 & 55.2 & 71 & 55.5 \\
\hline $\begin{array}{l}\text { Updating information about } \\
\text { organisation to customers }\end{array}$ & 57 & 59.4 & 91 & 71.1 \\
\hline $\begin{array}{l}\text { Maintaining external } \\
\text { communication }\end{array}$ & 77 & 80.2 & 103 & 80.5 \\
\hline $\begin{array}{l}\text { Maintaining internal } \\
\text { communication }\end{array}$ & 75 & 78.1 & 105 & 82 \\
\hline Media relations activities & 65 & 67.7 & 76 & 59.4 \\
\hline Writing press releases & 75 & 78.1 & 84 & 65.6 \\
\hline
\end{tabular}

In responding to this crisis, organizations coordinated with government since the latter provided information about COVID-19 and drew up health protocols that can be implemented in organizations to keep internal and external publics safe. Therefore, male and female public relations practitioners did not implement programs involving public participation physically to minimize the spread of the virus. They also changed their direct programs to virtual programs by using digital platforms. Moreover, they got updated information and policies from government to prevent and reduce workplace exposure to this virus. "Nah, it means that I posted about it, Sir. For instance, about the campus holiday, based on the instruction of the government" (Informant 2, Male).

In a situation filled with uncertainty, organizations communicate with their publics through official channels. Websites played a pivotal role and became the best tool to disseminate official information from organizations to prevent bias. Public relations practitioners used websites to optimize the dissemination of organizational information amidst the crisis. "We use it 
to prevent confusion information received by the publics, students, and faculty members. The information should be single and understandable," said informant 2 .

In facing a crisis like the COVID-19 pandemic, maintaining internal communication helps organizations ensure that business will not get worse. Internal communication aims to maintain understanding in the implementation of work plans. "We intensively communicate with employees online and ensure the same understanding to work together," said informant 1 . Informant 2 shared that "The meeting brings external issues of the university, and then those issues are discussed in order to find solutions." It became essential to ensure that employees received vital information from the organization supporting their work. Internal media functioned to keep employees informed as the crisis developed and changed, and about how organizations adjusted it.

Meanwhile, maintaining external publics in this pandemic was crucial in communicating and sharing compassion and responsiveness. This was achieved by listening and understanding what the publics needed to feel calm and safe, and by providing open and transparent information. "We visited to communities around Grand Ambarukmo. We also try, how we can share with the communities in this pandemic. So, what we did was, we gave aids to some communities around our hotel. We did it because we want to be present and feel this situation together," said informant 3.

The COVID-19 pandemic faced by most organizations in the world highlights the strengths of social media. The data shows that both male and female public relations practitioners evaluate the importance of social media. However, it shows that female public relations practitioners use social media more than males. The main reason for using social media is to help organizations develop creative new ways to connect with and inspire its publics. "So, our focus right now is using social media. How we can inform messages virtually. Okay, we are still open, and so on [..]. We are actively use social media, particularly in this pandemic. This becomes a way to keep connecting the publics and public trust" said informant 3. To maximize the dissemination of information, public relations practitioners asked all employees to repost messages on their personal social media accounts. "Nah, what we can do is asking all staffs [sic] and faculty members to repost messages we posted on Mercubuana's official social media accounts" said informant 2 .

Although organizations face the problematic situation of COVID-19, male public relations practitioners argue that engaging with the communities in which organizations operate is essential since the pandemic has an impact on the economy. "We care to [sic] the community. To reduce the 
spread of Covid-19, we gave them aids to fulfil their needs" said informant 2. Male public relations practitioners also tend to build media relations and distribute press releases to media to get news coverage both in conventional and digital media.

In this pandemic, corporate social responsibility (CSR) became a matter of how the organizations' brand interacted with their publics. Through this program, the organization also communicates and shares compassion and responsiveness with the publics. The data reveals that female public relations practitioners tended to implement CSR programs. They also preferred to handle consumer complaints and to update customers with organizational information to keep their trust in the organization.

\section{Discussion}

The COVID-19 pandemic has brought an interesting perspective to the opportunities that can be tackled by organizations. Regardless of the legitimation and authority of male and female public relations practitioners, they have the same perception towards the pandemic. They both evaluate it as opportunities for bringing organizations to a higher level. The crisis encourages organizations to make quick and effective decisions to save and sustain themselves by quickly adapting, re-planning communication strategies, developing creativity, innovating products, and keeping public trust.

Valuing the crisis as an opportunity for organizations to advance means that in this pandemic, both male and female public relations practitioners have a good understanding of how to respond by prioritizing the organizations' sustainability and development and the publics' safety. Having experience as a public relations practitioner for more than three years is an excellent foundation for understanding and tackling the public relations crisis. However, seeing a crisis as opportunity, particularly in this pandemic, validates the standard principles of crisis communication, specifically that the function of public relations practitioners is to help the power elite protect organizations (Tyler, 2005).

Public relations practitioners first acquire the hegemonic notion of crisis as opportunity instead of threat in college or at training. They learn how to solve a crisis by seeing opportunities to find solutions. In this pandemic, this doctrine has emphasized the importance of public relations in the organization. The function of public relations is not only about glossing organizations' reputation; organizations should also strategically apply public relations activities to achieve their goals and objectives (Yilmaz, 2009). In this pandemic, public relations practitioners become a shield to protect the organization with their ability to understand situations, re-plan 
communication strategies, and implement and evaluate programs, and create and disseminate messages that keep the public trust. However, most public relations practitioners remain at the technical level (Grunig, 2020) where they are not directly involved in making huge decisions. They only implement decisions.

The COVID-19 pandemic has tested public relations practitioners' ability to master digital technology to support their work, disseminate information, and engage with the publics. These practitioners are compelled to acquire information technology competencies to adjust to this situation. The knowledge and skills of public relations practitioners in information technology are pivotal in this pandemic. Those with information technology competencies can even utilize social media with other forms of virtual communication (Sriramesh \& Duhé, 2009). Utilizing and integrating digital media, for instance, can massively enhance their strategies' reach and influence.

Information communication technology competencies have become primary competencies of public relations since future communication programs will be shifted online. Public relations practitioners will use information communication technology even after the COVID-19 pandemic to 1) understand using online and social media monitoring the problems faced by organizations; 2) plan and implement the communication programs, taking into account the reality that the public cannot physically participate; and 3) evaluate programs based on public opinion in the virtual world. Therefore, public relations practitioners should keep themselves updated on developments in information communication technology which is dynamically changing.

This study reveals that during the COVID-19 pandemic, social media has become a communication tool powerfully reaching the public in disseminating messages. It is in line with a study stating that social media is a tool for managing crisis (Graham et al., 2015). Organizations share messages of compassion and empathy with what the public feels. Therefore, in communicating with the public on social media, a human approach should be employed since it is a pivotal basis for creating messages that will help the public feel reassured while strengthening organizations' brand and values offering.

This study's finding is also in line with a study saying that in a crisis social media plays an essential role in effectively communicating with the public (Ngai \& Falkheimer, 2017). With the policy of physical distancing during the COVID-19 pandemic, social media has become the primary tool to engage with the public and access information (Gao et al., 2020) China. We assess the prevalence of mental health problems and examine 
their association with social media exposure. A cross-sectional study among Chinese citizens aged $\leq 18$ years old was conducted during Jan 31 to Feb 2, 2020. Online survey was used to do rapid assessment. Total of 4872 participants from 31 provinces and autonomous regions were involved in the current study. Besides demographics and social media exposure (SME).

It is also interesting to note that organizations should be present to the public during this pandemic by listening to what they want from the organizations. Hence, both male and female public relations practitioners use social media to monitor and listen to what the public say about the organizations. This finding supports the studies of Altug Akay, Andrei Dragomir, and Bjorn Erlandsson (2015) and Nick Anstead and Ben O'Loughlin (2015), which state that social media can be utilized to analyse and monitor public opinion since publics share their thoughts on their social media account. Furthermore, in the situation of COVID-19, monitoring public opinion becomes a basis for creating creative content that connect and engage with the public.

Social media is inexpensive and useful in sharing essential organizational updates during the COVID-19 pandemic since these platforms can provide two-way communication between the organizations and their publics. Therefore, both male and female public relations practitioners optimize the use of social media to massively communicate organization-related activities, policies, and changes to reinforce public trust. However, female public relations practitioners tend to do this more than males. This finding validates a study of Cara Booker, Yvonne Kelly, and Amanda Sacker (2018) that showed females generally using social media more than males. In this pandemic, it is the female public relations practitioners that intensively maintain the organizations' existing relationships with the public. Interconnection with the public becomes an essential matter for them since feminine values have been internalized in their profession as public relations practitioners (Grunig et al., 2000).

It is critical to keep the internal and external public informed, especially with this pandemic bringing challenges for public relations practitioners to enlarge the communication addressed to internal and external publics.

Interestingly, male public relations practitioners tend to enlarge external communication more while females prefer internal communication. This findingstrengthens a studyofBonka Bovena, RobertKraut, andDavidFrohlich (2001) that states that it is more gratifying when females communicate and maintain relationships with people. Female public relations practitioners focus more on strengthening internal communication to ensure that employees are safe and connected. This coincides with the value of care identified with female public relations practitioners (Driskill, 2018). If one 
department in an organization handles internal communication, another department can focus more on external communication, this time with more male public relations practitioners involved.

Despite the same dominant activities done by male and female public relations practitioners, males tend more to implement community relations programs, conduct media relations, and write press releases. Females prefer to implement CSR programs, handle customer complaints, and update organizational information. These activities highlight that female public relations practitioners give more attention to communication programs dealing with customers by building strong relationships with them. Male public relations practitioners focus more on winning the market by strengthening the organization's image and reputation through publicity in the media. It is noteworthy that building relations with the media to publicize the organization is not easy for female public relations practitioners. They have fewer opportunities to use their talents and abilities to build media relations (Beatty, 2013).

\section{Conclusion}

During the COVID-19 pandemic, both male and female public relations practitioners have a specific understanding of crisis communication, ways of facing the crisis, and public relations activities. The results show that both male and female public relations practitioners evaluate the crisis as opportunities. To face the crisis, they need to enhance technology competencies and build relationships with the public by providing updated information. However, in disseminating information using social media, more female public relations practitioners than males are involved.

In this crisis, both male and female public relations practitioners minimize or do not conduct direct communication programs involving physical public participation. Nevertheless, in terms of enlarging communication with the public, male public relations practitioners tend to communicate with the external public, while females tend to do it with the internal public. Despite the same dominant activities done by male and female public relations practitioners, males tend to implement community relations programs, conduct media relations, and write press releases. Meanwhile, females prefer to implement CSR programs, handle customer complaints, and update organizational information.

Finally, this study proves pivotal roles of public relations practitioners to keep their organization surviving in the COVID-19 pandemic by doing communication programs. Specifically, the findings illustrate how male and female public relations practitioners adapt to this hard situation by positively understanding the crisis and enhancing their competencies to be able to 
optimize the use of digital media. This study also shows some similarities and differences between male and female public relations practitioners in dealing with the COVID-19 pandemic.

\section{Limitation and Study Forward}

This study establishes that there are some different ways in dealing with the COVID-19 pandemic between male and female public relations professionals. However, the differentiation of the business sectors in which the informants belong-education, hotel, hospital, government, agency, and media-makes it difficult to firmly attribute the differences in practices to gender since those business sectors have their own uniqueness in running their business. Therefore, public relations professionals might be differently tasked to achieve the organizations' objectives. Future research can investigate male and female public relations professionals from the same business sector in order to isolate the gender factor.

Furthermore, the sample of analysis of this study was small and the resulting data was nominal since the participants could choose from among several answers options provided according to the situation they dealt with. Therefore, it was analysed by using only descriptive statistics. Nevertheless, the findings may serve to alert public relations scholars and practitioners to some issues involved in the gender of public relations in handling the crisis of the COVID-19. Moreover, this study also informs future research to enlarge the sample and use interval data in order to conduct hypothesis testing to investigate the significant differences between male and female public relations practitioners in dealing with the COVID-19 pandemic. Understanding best practices in tackling the pandemic crisis by combining how male and female public relations practitioners deal with it can help organizations avoid the worst conditions. 


\section{References}

Akay, A., Dragomir, A., \& Erlandsson, B. E. (2015). A novel data-mining approach leveraging social media to monitor consumer opinion of Sitagliptin. IEEE Journal of Biomedical and Health Informatics, 19(1), 389-396. https://doi.org/10.1109/JBHI.2013.2295834

Andsager, J. L., \& Hust, S. J. T. (2005). Differential gender orientation in public relations: Implications for career choices. Public Relations Review, 31(1), 85-91. https://doi.org/10.1016/j.pubrev.2004.09.002

Anstead, N., \& O'Loughlin, B. (2015). Social media analysis and public opinion: The 2010 UK general election. Journal of Computer-Mediated Communication, 20(2), 204-220. https://doi.org/10.1111/ jcc4.12102

Baltar, F., \& Brunet, I. (2012). Social research 2.0: Virtual snowball sampling method using Facebook. Internet Research, 22(1), 57-74. https://doi.org/10.1108/10662241211199960

Beatty, T. U. F. (2013). A historical and analytical study of feminization in the field of public relations (Unpublished thesis, Southeastern University). https://firescholars.seu.edu/cgi/viewcontent. cgi?article $=1023 \&$ context $=$ honors

Boneva, B., Kraut, R., \& Frohlich, D. (2001). Using e-mail for personal relationships: The difference gender makes. American Behavioral Scientist, 45(3), 530-549. https://doi.org/10.1177/00027640121957204

Booker, C. L., Kelly, Y. J., \& Sacker, A. (2018). Gender differences in the associations between age trends of social media interaction and well-being among 10-15 year olds in the UK. BMC Public Health, 18(1), 1-12. https://doi.org/10.1186/s12889-018-5220-4

Campbell, D., \& Craig, T. (2005). Organizations and the business environment. Elsevier ButterworthHeinemann.

Coombs, W. T. (2007). Crisis management and communications. Institute for Public Relations, (1), 1-14. https://doi.org/http://hdl.handle.net/123456789/96

Creswell, J. W. (2014). Research design: Qualitative, quantitative, and mixed methods approaches (4th ed.). SAGE Publication, Inc.

Daymon, C., \& Demetrious, K. (2010). Gender and public relations: Perspectives, applications and questions. PRism, 7, 1-9.

Driskill, Q. L. (2018). In a different voice. Journal of Feminist Studies in Religion, 34(1), 93-96. https://doi. org/10.2979/jfemistudreli.34.1.14

Fall, L. T. (2004). The increasing role of public relations as a crisis management function: An empirical examination of communication restrategising efforts among destination organisation managers in the wake of 11th September, 2001. Journal of Vacation Marketing, 10(3), 238-252. https://doi. org/10.1177/135676670401000304

Flynn, T. T. (2014). Relations practitioners in Canada. Canadian Journal of Communication, 39, 361-384.

Gao, J., Zheng, P., Jia, Y., Chen, H., Mao, Y., Chen, S., ... Dai, J. (2020). Mental health problems and social media exposure during COVID-19 outbreak. PLOS ONE, 15(4), 1-10. https://doi.org/10.1371/journal. pone. 0231924

Graham, M. W., Avery, E. J., \& Park, S. (2015). The role of social media in local government crisis communications. Public Relations Review, 41(3), 386-394. https://doi.org/10.1016/j. pubrev.2015.02.001 
Grunig, L. A. (2020). Power in the public relations department. In Grunig, L. A., \& Grunig, J. E. (Eds), Public relations research annual (pp. 115-156). Routledge.

Grunig, L. A., Toth, E. L., \& Hon, L. C. (2000). Feminist values in public relations. International Journal of Phytoremediation, 21(1), 49-68. https://doi.org/10.1207/S1532754XJPRR1201_4

Hudecheck, M., Sirén, C., Grichnik, D., \& Wincent, J. (2020). How companies can respond to the Coronavirus. MIT Sloan Management Review.

ILO-SCORE Indonesia. (2020). Temuan-Temuan Utama Survei Usaha Terdampak COVID-19 dari program ILO-SCORE Indonesia. 6. Retrieved from https://www.ilo.org/wcmsp5/groups/public/---asia/---robangkok/---ilo-jakarta/documents/publication/wcms_745054.pdf

Mahar, I. (2020). Impact of Covid-19 on Global Economy Structure - Modern Diplomacy. Modern Diplomacy. https://moderndiplomacy.eu/2020/04/22/impact-of-covid-19-on-global-economystructure/

Maiorescu, R. D. (2016). Crisis management at General Motors and Toyota: An analysis of genderspecific communication and media coverage. Public Relations Review, 42(4), 556-563. https://doi. org/10.1016/j.pubrev.2016.03.011

Marra, F. J. (1998). Crisis communication plans: Poor predictors of excellent crisis public relations. Public Relations Review, 24(4), 461-474. https://doi.org/10.1016/S0363-8111(99)80111-8

Marx_PR and Marketing_How to Communicate During COVID-19-Business 2 Community. (n.d.).

Ngai, S. B. C., \& Falkheimer, J. (2017). How IKEA turned a crisis into an opportunity. Public Relations Review, 43(1), 246-248. https://doi.org/10.1016/j.pubrev.2016.12.003

Olsson, E.-K. (2014). Postprint crisis communication in public organizations: Dimensions of crisis. 22(2), $113-125$.

Sriramesh, K., \& Duhé, S. C. (2009). Extending cultural horizons: Political economy and public relations. Public Relations Review, 35(4), 368-375. https://doi.org/10.1016/j.pubrev.2009.08.005

Tyler, L. (2005). Towards a postmodern understanding of crisis communication. Public Relations Review, 31(4), 566-571. https://doi.org/10.1016/j.pubrev.2005.08.017

Wade, M., \& Bjerkan, H. (2020). Three proactive response strategies to COVID-19 business challenges. Mit Sloan Management Review, pp. 1-5.

Wu, A. W., Connors, C., \& Everly, G. S. (2020). COVID-19: Peer support and crisis communication strategies to promote institutional resilience. Annals of Internal Medicine, 172(12), 822-823. https://doi. org/10.7326/M20-1236

Yilmaz, B. S. (2009). Probable applications of complex networks in public relations practices: A scenariobased approach Burcu Selin Yilmaz and Ozgur Devrim Gunel. 6 (January 2009), 1-16. 


\section{Grant Support Details}

Author Contributions: Conceptualization, N.R. Santoso., E.A.S.K. Dewi., H. Arviani., and Z.A. Achmad., methodology, N.R. Santoso., and E.A.S.K. Dewi., investigation, N.R. Santoso., and E.A.S.K. Dewi., data curation, N.R. Santoso., and H. Arviani., writing draft preparation, N.R. Santoso., writing-review and editing, N.R. Santoso., H. Arviani., and Z.A. Achmad., project administration, N.R. Santoso. All authors have read and agreed to the published version of the manuscript.

Funding: The authors received no specific funding for this work.

Acknowledgements: The authors would like to thank all the public relations professionals that participated in the study for their time and commitment with the study.

Conflict of Interest: The authors declare no conflict of interest.

\section{About the Authors}

NOBERTUS RIBUT SANTOSO is an Assistant Professor at the Department of Communication, Universitas Atma Jaya Yogyakarta. He is currently taking his $\mathrm{PhD}$ at Communication Research, College of Mass Communication, University of the Philippines Diliman. Nobertus obtained his MA at Universitas Gadjah Mada. His research interests are on public relations, gender, and social media issues. He is also a Country Representative of Indonesia at Asia Pacific Public Relations Research and Education Network (APPRREN) (corresponding author: nobertus.ribut@uajy.ac.id)

EMANUELA AGRA SARIKA KURNIA DEWI is an Assistant Professor at the Department of Tourism, Sekolah Tinggi Pariwisata Ambarrukmo. She obtained her MA from Universitas Gadjah Mada. Her research interests are in the fields of public relations and tourism.

HEIDY ARVIANI is an Assistant Professor at the Department of Communication, Universitas Pembangunan Nasional "Veteran" Jawa Timur. She obtained her MA in Universitas Gadjah Mada in 2011, studying culture jamming and discourse analysis. She is interested in marketing, branding, advertising, health communication and digital communication.

ZAINAL ABIDIN ACHMAD is an Associate Professor at the Department of Communication, Universitas Pembangunan Nasional "Veteran" Jawa Timur. He obtained his PhD at Universitas Airlangga. He is also working in the development sector (NGOs) to promote Index Democracy Indonesia in East Java since his participation at UNDP IDI-Project. He has contributed to a series of exit poll for elections in Indonesia. He has been conducting opinion research for some local elections. He has interest in media and cultural studies, ethnography, and sociology of communication. 
